
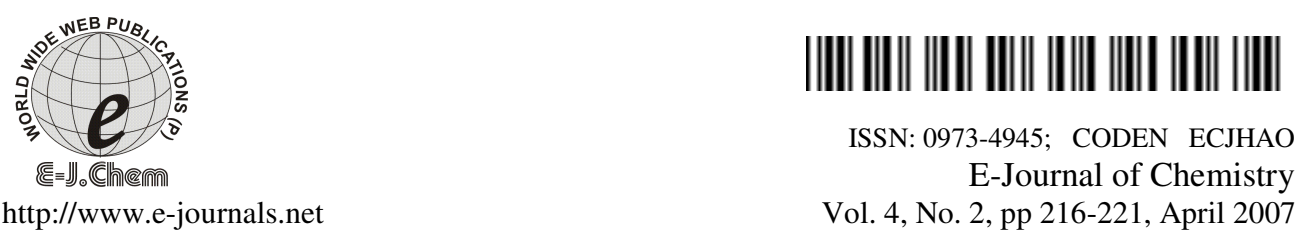

\title{
Simple and Rapid Methods for the Analysis of Captopril in Dosage Forms
}

\author{
H. CHANDRU* and A.C. SHARADA \\ *Department of Studies in Biochemistry, \\ University of Mysore, \\ Manasagangotri, Mysore-57006, Karnataka, India. \\ Department of Biochemistry, \\ Yuvaraja's College University of Mysore, \\ Mysore-570005, Karnataka, India.
}

Received 16 October 2006; Revised 7 December 2006; Accepted 24 December 2006

\begin{abstract}
Two indirect methods are described for the micro determination of captopril using hexacyanoferrate (III) as reagent. The reaction used for titrimetry proceeds at room temperature and will be complete in 10 minute with a stoichiometry of 1:1 with respect to the oxidant and captopril. The reaction product used for spectrophotometric determination shows the absorption maximum at $510 \mathrm{~nm}$. The Beer's law is obeyed over the concentration range $0.25-12.00 \mu \mathrm{g} \mathrm{mL} \mathrm{L}^{-1}$, the molar absorptivity and Sandell sensitivity for the system being $9.14 \times 10^{3} \mathrm{~L} \mathrm{~mol}^{-1} \mathrm{~cm}^{-1}$ and $23.78 \mathrm{ng} \mathrm{cm}$, respectively. The limit of detection and quantification are found to be 0.08 and $0.26 \mu \mathrm{g} \mathrm{m}^{-1}$, respectively. Both procedures have been applied to the determination of captopril in tablets. The results have been statistically compared with those obtained by the official (BP) method.
\end{abstract}

Keywords: Captopril, Hexacyanoferrate, dosage forms, Titrimetry, Spectrophotometry

\section{Introduction}

Captopril, 1-(3-mercapto-2-D-methyl-1-oxopropyl)-1-proline, is an antihypertensive drug widely prescribed in the treatment of hypertension and chronic congestive heart failure. It acts primarily by inhibiting the angiotensin-converting enzyme. Simple methods for its assay in technical and formulation grade sample are necessary for routine analysis and quality evaluation. The most widely used technique for the determination of captopril is high 
performance liquid chromatography ${ }^{\mathbf{1}-5}$ but the procedures based on this technique require either derivatisation of the compound or selective detectors and elaborate multistep extraction. Gas chromatographic methods reported either involve derivatisation ${ }^{6,7}$ or lack the required sensitivity ${ }^{8}$ or restricted to body fluids ${ }^{9-12}$. Several other instrumental methods such as differential polarography ${ }^{\mathbf{1 3}}$, capillary electrophoresis ${ }^{14}$, specrofluorimetry $^{\mathbf{1 5}}$, amperometry $^{16}$ and coulometry ${ }^{17}$ have been applied for the assay of drugs in pharmaceuticals. Quantification of captopril has also been achieved by radio ${ }^{18}$ and enzyme ${ }^{19}$ immunoassay methods. Literature on the titrimetric methods for the analysis of captopril is scanty. Three methods ${ }^{\mathbf{2 0 - 2 2}}$ reported use silver nitrate as the reagent.

Direct spectrophotometric methods based on diazotization and coupling reaction ${ }^{23}$, redox reaction using Folin-Ciolteu reagent ${ }^{24}$ and molybdophosphoric acid ${ }^{25}$ and complex formation reaction involving dithiopyridine ${ }^{26}$, phenylfurazone ${ }^{27}$ and palladium (II) chloride $^{28}$ have been used for the determination of the drug. The procedures suffer from one or the other disadvantage such as insufficient sensitivity ${ }^{23}\left(5-20 \mathrm{mgmL}^{-1}\right)$, selectivity ${ }^{24}, 25$ or longer contact time $^{27}(1 \mathrm{~h})$. Indirect spectrophotometric methods involving the measurement of decrease in absorbance cresyl fast violet acetate ${ }^{\mathbf{2 9}}$, celestine blue $^{30}$ and 2,2-diphenyl-1-picryl hydrazyl ${ }^{31}$ have also been reported for the assay captopril. However, the accuracy and reliability of these methods are heavily dependent on the purity of the coloured reagents. In search of more convenient methods, titrimetric and spectrophotometric investigations of the oxidation reaction between captopril and hexacyanoferrate (III) have been carried out and their application to the analysis of authentic samples and dosage forms have been examined.

\section{Experimental}

\section{Apparatus}

A Systronics model 106 digital spectrophotometer with $1 \mathrm{~cm}$ matched glass cells was used for absorbance measurements.

\section{Reagents and materials}

All chemicals used were of analytical reagent grade and distilled water was used to prepare all solutions. A standard solution of $0.02 \mathrm{M}$ potassium hexacyanoferrate (III) was prepared by dissolving $6.5852 \mathrm{~g}$ of reagent in one liter of water in a volumetric flask. Sodium thiosulphate solution $(\sim 0.02 \mathrm{M})$ was prepared in water and standardized iodometrically ${ }^{32}$. Zinc sulphate $(30 \%)$, potassium iodide $(10 \%)$, hydrochloric acid $(5 \mathrm{M})$ and starch indicator (1\%) solutions were prepared in the usual way and used in titrimetric work. Hexacyanoferrate (III) $\left(100 \mu \mathrm{g} \mathrm{mL}^{-1}\right)$ obtained by stepwise dilution of $0.02 \mathrm{M}$ solution, $0.25 \% 1,10$-phenanthroline, $1.5 \mathrm{M}$ hydrochloric acid and $0.5 \mathrm{M}$ sodium carbonate solutions were employed for spectrophotometric investigation.

\section{Titrimetry}

To a $10 \mathrm{~mL}$ aliquot containing 1-8 $\mathrm{mg}$ of captopril in a titration flask were added $2 \mathrm{~mL}$ of $5 \mathrm{M}$ hydrochloric acid, $10 \mathrm{~mL}$ of $0.02 \mathrm{M}$ hexacyanoferrate (III) and $10 \mathrm{~mL}$ of $30 \%$ zinc sulphate solutions, mixed well and kept aside for 20 minute with occasional shaking. Then, $5 \mathrm{~mL}$ of $10 \%$ potassium iodide solution were added and the liberated iodine was titrated with $0.02 \mathrm{M}$ thiosulphate solution in the presence of starch indicator. A blank experiment was carried out in the same manner. Amount of drug was calculated from the equation: 
$\operatorname{Drug}(\mathrm{mg})=\left(\mathrm{V}_{1}-\mathrm{V}_{2}\right) \mathrm{MR} / \mathrm{n}$

Where $\mathrm{V} 1=$ volume of thiosulphate consumed in the blank titration, $\mathrm{mL}$;

$\mathrm{V}_{2}=$ volume of thiosulphate consumed in the sample titration, $\mathrm{mL}$;

$\mathrm{M}=$ relative molar mass of drug;

$\mathrm{R}=$ molarity of hexacyanoferrate (III)

and $n=$ number of moles hexacyanoferrate (III) reacting per mole of drug.

\section{Spectrophotometry}

A $3.0 \mathrm{~mL}$ aliquot of standard drug solution containing $2.5-120 \mu \mathrm{g}$ of captopril was placed in a $10 \mathrm{~mL}$ volumetric flask to which $1.5 \mathrm{~mL}$ of $5 \mathrm{M}$ hydrochloric acid and $1 \mathrm{~mL}$ of $100 \mu \mathrm{g} \mathrm{mL}^{-1}$ of hexacyanoferrate (III) solutions were added. The flasks and contents were swirled, placed in a boiling water bath for 10 minute. Then, the flasks were cooled, $1.5 \mathrm{~mL}$ of $0.5 \mathrm{M}$ sodium carbonate were added followed by $1 \mathrm{~mL}$ of $0.25 \%$ 1,10-phenanthroline and diluted to mark with water. The coloured product was measured at $510 \mathrm{~nm}$ against the reagent blank. The concentration of drug in the unknown was deduced from the calibration graph or computed from the regression equation.

\section{Tablets}

Twenty tablets were weighed and ground into a fine powder. A quantity of powder containing $100 \mathrm{mg}$ of active ingredient was weighed accurately into a $100 \mathrm{~mL}$ volumetric flask, $60 \mathrm{~mL}$ of water added and shaken thoroughly for about 20 minute to extract the drug. Diluted to the mark with water, mixed well and filtered through a Whatman No. 41 filter paper. First ten of the filtrate was rejected. A convenient volume was assayed by titrimetry using the general procedure. The filtrate was diluted appropriately to get $40 \mu \mathrm{g} \mathrm{mL}^{-1}$ and a suitable volume was subjected to analysis by spectrophotometry.

\section{Results and Discussion}

Both methods are based on the oxidation of captopril with excess of hexacyanoferrate (III). In titrimetry, the excess oxidant, after oxidation was determined iodometrically in the presence of zinc sulphate, there by allowing indirect assay of captopril, whereas in spectrophotometry, hexacyanoferrate (II), a reaction product is determined by reacting it with 1,10-phenanthroline, thus permitting the indirect estimation of captopril.

The reaction variables were optimized by varying each variable while keeping others constants for obtaining constant stoichiometry in titrimetry and reproducible and maximum absorbance in spectrophotometry. The oxidation reaction was found to be quantitative in hydrochloric acid medium and $2 \mathrm{~mL}$ of $5 \mathrm{M}$ acid in a total volume $25 \mathrm{~mL}$ was found to produce a constant molar ratio. In the back titration of hexacyanoferrate (III) iodometrically, zinc sulphate was added to ensure quick and irreversible oxidation of iodide by hexacyanoferrate (III) ${ }^{\mathbf{3 3}}$ through the removal of hexacyanoferrate (II) formed ${ }^{34}$ as the slightly soluble potassium zinc hexacyanoferrat (II). The oxidation of the drug by hexacyanoferrate (III) was slow at room temperature and found to be complete in 20 minute under specified acid and oxidant concentrations. Two fold increases in excess of hexacyanoferrate (III) had no effect on the stoichiometry of the reaction. For the range studied $(1-8 \mathrm{mg})$, a $10 \mathrm{~mL}$ volume of $0.02 \mathrm{M}$ hexacyanoferrate (III) gave stoichiometric results. Under the stated experimental conditions, 2 moles of hexacyanoferrate (III) were consumed per mole of captopril. The linearity between the amount of the drug and the titration end point is apparent from the value of the correlation coefficient, $\mathrm{r}(0.9982)$ obtained by the best fit-line via linear least squares treatment. 
Spectrophotometric method is based on the oxidation reaction of captopril with hexacyanoferrate (III) under acidic conditions and subsequent determination of hexacyanoferrate (II), the reduced form of the oxidant, by reacting with 1,10phenanthroline under mildly acidic conditions ( $\mathrm{pH} 3-4)$ resulting in the formation of red colour $^{35}$ which could be measured at $510 \mathrm{~nm}$. Captopril when added in increasing amounts to a fixed amount of hexacyanoferrate (III), there is a concomitant rise in the concentration of hexacyanoferrate (II), after the oxidation reaction. This is observed as a proportional increase in the absorbance of the reaction mixture on adding 1, 10phenanthroline. The oxidation reaction was slow at room temperature and was found to be complete when heated with $5 \mathrm{M}$ hydrochloric acid in a boiling water-bath for 10 minutes. For the range investigated $(2.5-120 \mu \mathrm{g}), 1 \mathrm{~mL}$ of $100 \mu \mathrm{g} \mathrm{mL}^{-1}$ hexacyanoferrate (III) and $1.5 \mathrm{~mL}$ of $5 \mathrm{M}$ hydrochloric acid were sufficient to effect oxidation. Since the colour reaction between hexacyanoferrate (II) and 1,10-phenanthroline takes place in the $\mathrm{pH}$ range $3-4,1.5 \mathrm{~mL}$ of $0.5 \mathrm{M}$ sodium carbonate solution were needed to raise the $\mathrm{pH}$ to about 3.5 before adding 1,10phenanthroline solution. The colour produced was found to be stable for several weeks.

Under the experimental conditions described, Beer's law is obeyed over the concentration range $0.25-12 \mu \mathrm{g} \mathrm{mL}^{-1}$. The linear regression equation:

$$
\mathrm{A}=0.01+0.04 \mathrm{C}(\mathrm{r}=0.9982)
$$

Where $\mathrm{A}$ is the absorbance and $\mathrm{C}$ is the concentration in $\mu \mathrm{g} \mathrm{mL^{-1 }}$. The apparent molar absorptivity was $9.14 \times 10^{3} \mathrm{~L} \mathrm{~mol}^{-1} \mathrm{~cm}^{-1}$ and Sandell sensitivity was $23.78 \mathrm{ng} \mathrm{cm}^{-2}$. The limit of detection was $0.0776 \mu \mathrm{g} \mathrm{mL}^{-1}$ and the limit of quantification as the lowest standard concentration, which could be determined with acceptable accuracy, and precision was $0.2589 \mu \mathrm{g} \mathrm{mL}^{-1}$.

\section{Accuracy and precision}

The accuracy and precision of the methods were checked by seven replicate determinations at 2,5 and $7 \mathrm{mg}$ levels by titrimetry and 30,60 and $90 \mu \mathrm{g}$ levels by spectrophotometry. The percent error was found to be less than 2 and the relative standard deviation found to be between 0.45 and 2.13 , which are indicative of satisfactory accuracy and repeatability. The results of the study are compiled in Table 1.

Table 1. Evaluation of accuracy and precision

\begin{tabular}{cccccccc}
\hline \multicolumn{3}{c}{ Titrimetry } & \multicolumn{4}{c}{ Spectrophotometry } \\
\hline $\begin{array}{c}\text { Amount } \\
\text { taken } \\
(\mathrm{mg})\end{array}$ & $\begin{array}{c}\text { Amount } \\
\text { found* } \\
(\mathrm{mg})\end{array}$ & $\begin{array}{c}\text { Error } \\
(\%)\end{array}$ & $\begin{array}{c}\text { RSD } \\
(\%)\end{array}$ & $\begin{array}{c}\text { Amount } \\
\text { taken } \\
(\mu \mathrm{g})\end{array}$ & $\begin{array}{c}\text { Amount } \\
\text { found* } \\
(\mu \mathrm{g})\end{array}$ & $\begin{array}{c}\text { Error } \\
(\%)\end{array}$ & $\begin{array}{c}\text { RSD } \\
(\%)\end{array}$ \\
\hline 2.00 & 2.04 & 2.0 & 2.13 & 30.00 & 29.93 & 0.23 & 0.93 \\
5.00 & 5.02 & 0.40 & 1.81 & 60.00 & 60.11 & 0.18 & 0.45 \\
7.00 & 7.06 & 0.86 & 1.32 & 90.00 & 90.07 & 0.07 & 0.45 \\
\hline
\end{tabular}

*Average value of seven determinations; RSD- Relative standard deviation

\section{Application}

The results for the determination of captopril in the three brands of tablets are given in Table 2. In which they are compared with those obtained using reported established methods ${ }^{35}$. Statistical analysis of the results by the variance-ratio test and t-test showed that there was no significant difference between the performance of the proposed method and reference methods in terms of reproducibility and accuracy. 
To ascertain the reliability of the methods, recovery test was performed by applying the technique of standard-addition, pure drug was added at three different levels and the total was found by the proposed methods. The test was repeated three times foe each level. The results of this study presented in Table 3 reveal that accuracy and precision of the methods were unaffected by various co-formulated substances such as lactose, talc, starch, magnesium stearate and sodium alginate.

Table 2. Results of analysis of tablets using the proposed methods

\begin{tabular}{|c|c|c|c|c|c|c|c|c|}
\hline \multirow{2}{*}{$\begin{array}{l}\text { Tablet } \\
\text { brand } \\
\text { name* }\end{array}$} & \multirow{2}{*}{$\begin{array}{c}\text { Label } \\
\text { claim, } \\
\text { mg per } \\
\text { tablet }\end{array}$} & \multicolumn{3}{|c|}{ Found $^{\psi}(\%$ recovery \pm SD $)$} & \multicolumn{2}{|c|}{$t_{\text {-value }}^{\#}$} & \multicolumn{2}{|c|}{ F-value $^{@}$} \\
\hline & & $\begin{array}{l}\text { Titrimetry } \\
(\mathrm{T})\end{array}$ & $\begin{array}{c}\text { Spectro- } \\
\text { Photometry } \\
(\mathrm{S})\end{array}$ & $\begin{array}{l}\text { Reference } \\
\text { methods }\end{array}$ & $\mathrm{T}$ & $\mathrm{S}$ & $\mathrm{T}$ & $\mathrm{S}$ \\
\hline$\overline{\text { Acetin }^{\alpha}}$ & 25.00 & $99.14 \pm 0.38$ & $97.96 \pm 0.85$ & $99.76 \pm 0.62$ & 1.84 & 3.60 & 2.66 & 1.88 \\
\hline \multirow[t]{2}{*}{ Angiopril $^{\beta}$} & 25.00 & $100.28 \pm 0.64$ & $102.23 \pm 1.02$ & $100.62 \pm 0.46$ & 0.92 & 3.24 & 1.94 & 4.90 \\
\hline & 50.00 & $98.10 \pm 0.36$ & $98.76 \pm 0.67$ & $97.56 \pm 0.38$ & 2.17 & 3.37 & 1.11 & 3.11 \\
\hline \multirow{2}{*}{ Captopril $^{\gamma}$} & 12.50 & $101.28 \pm 0.53$ & $101.66 \pm 0.96$ & $100.84 \pm 0.56$ & 1.20 & 1.61 & 1.12 & 2.94 \\
\hline & 25.00 & $98.63 \pm 0.66$ & $99.35 \pm 0.74$ & $98.78 \pm 0.26$ & 0.48 & 1.70 & 6.44 & 8.10 \\
\hline
\end{tabular}

Table 3. Results of recovery study using standard-addition method

\begin{tabular}{ccccccccc}
\hline \multirow{3}{*}{$\begin{array}{c}\text { Tablet } \\
\text { brand } \\
\text { name } \\
\text { studied }\end{array}$} & $\begin{array}{c}\text { Amount Amount } \\
\text { of drug } \\
\text { in } \\
\text { extract, } \\
(\mathrm{mg})\end{array}$ & $\begin{array}{c}\text { Trug, } \\
\text { drug })\end{array}$ & $\begin{array}{c}\text { Total } \\
\text { found, } \\
(\mathrm{mg})\end{array}$ & $\begin{array}{c}\text { Recovery* } \\
\text { of pure } \\
\text { drug } \\
\text { added, } \\
(\%)\end{array}$ & $\begin{array}{c}\text { Amount } \\
\text { of drug } \\
\text { in } \\
\text { extract, } \\
(\mu \mathrm{g})\end{array}$ & $\begin{array}{c}\text { Amount } \\
\text { of pure } \\
\text { drug, } \\
(\mu \mathrm{g})\end{array}$ & $\begin{array}{c}\text { Total } \\
\text { found, } \\
(\mu \mathrm{g})\end{array}$ & $\begin{array}{c}\text { Recovery* } \\
\text { of pure } \\
\text { drug } \\
\text { added, } \\
(\%)\end{array}$ \\
\hline Acetin & 0.9914 & 3.00 & 3.934 & 98.08 & 19.59 & 30.00 & 48.96 & 97.90 \\
$(25 \mathrm{mg})$ & 0.9914 & 5.00 & 5.850 & 97.17 & 19.59 & 50.00 & 70.54 & 101.90 \\
& 0.9914 & 7.00 & 7.79 & 97.12 & 19.59 & 80.00 & 102.16 & 103.21 \\
Angiopril & 1.0000 & 3.00 & 4.087 & 102.90 & 20.00 & 30.00 & 51.89 & 102.29 \\
$(25 \mathrm{mg})$ & 1.0000 & 5.00 & 6.043 & 100.86 & 20.00 & 50.00 & 70.89 & 101.78 \\
& 1.0000 & 7.00 & 8.109 & 101.56 & 20.00 & 80.00 & 99.63 & 99.53 \\
Captopril & 0.9863 & 3.00 & 4.048 & 102.06 & 19.73 & 30.00 & 50.78 & 103.50 \\
$(25 \mathrm{mg})$ & 0.9863 & 5.00 & 5.95 & 99.27 & 19.73 & 50.00 & 70.25 & 101.04 \\
& 0.9863 & 7.00 & 7.89 & 98.62 & 19.73 & 80.00 & 101.09 & 101.69 \\
\hline
\end{tabular}

* Average value of three trials.

\section{Conclusions}

The methods are simple, sensitive and their application to the determination of the micro and sub micro amounts of captopril has been demonstrated.

\section{Acknowledgment}

The authors thank Torrent Pharmaceuticals, Ahmedabad, India, for gifting pure sample of captopril. We also thank to Prof. K.S. Rangappa Chairman Department of chemistry, University of Mysore to provided laboratory facilities to perform this work. The author wishes to acknowledge the University for the UGC minor project. 


\section{References}

1. Khedr A and EL-Sherif H, Biomed Chromatogr, 1998, 12, 57.

2. Russel J, Mc keown J A, Hensman C, Smith W E and Reglinski J, J Pharm Anal, 1998, 15, 1757.

3. Bald E, Sypniewski S, Fresenins, J Anal Chem, 1997, 358, 554.

4. Wieling J, Hendrikis G, Tamminga W.J, Hemepenius J, Mensink C K, Oosterhuis B and Jonkman J H G, J .Chromatogr, $1996,730,381$.

5. Cavrini V, Gatti R, Dipietra A M and Raggi M A, Chromatographia, 1987, 23, 680.

6. Jemal M and Cohen A I, Anal. Chem, 1985, 57, 2407.

7. Liu Y C, Wu H L, Kou H S, Chen S H and Wu S M, Anal Lett, 1995, 28, 1465.

8. Liu C H, Liu S L, Chen H N and Xie X T, Sepu, 1998, 16, 62.

9. Franklin M E, Addson R S, Baker P U and Hooper W D, J Chromatogr Biomed Appl, 1998,705, 47.

10. Leis H J, Leis M, Weiz W and Malle, J Chromatogr Biomed Appl, 1990, 94, 299.

11. Ito T, Matsuki Y, Kurihara H and Nambara T, J, Chromatogr Biomed Appl, 1987, 6179.

12. Jemal M, Ivashkiv E and Cohen A I, Biomed. Mass Spectrum, 1985, 12, 664.

13. Fraga J M G, Abizanda A I J, Moreno F J and Leon J J A, Talanta 1998, 46, 75.

14. Russel J, Rabenstein D L, Anal. Biochem, 1996, 242, 136

15. Segarra Gueerreo R, Sagrado Vives S and Martinez Calatagnd J, Microchem J, 1991, 43, 176.

16. Korieanac Z, Jovanovic T and Stankovic B, Pharmazie, 1995, 50, 299.

17. Nikolic Kand Velasevic K, Acta Pol. Pharm, 1991, 48, 5.

18. Tu J I, Brennan J, Stouffer B and Ecklelman W C, The Drug Monitor, 1990, 12, 404.

19. Kinoshita H, Nakamaru R, Tanaka S, Tohira Y and Sawada M, J Pharm Sci, 1986, 75,711.

20. Nikolic K and Velasevic K R, J Pharm Belg, 1990, 45, 17.

21. Nikolic K and Velasevic K R, Pharmzie, 1989, 44155.

22. Buzanova M M, and Kasaudi I V, Zavod Lab, 1995, 61, 7.

23. Sanghavi N M, Samarth M M and Mathru R S P S, Indian Drugs, 1991, 28, 489.

24. Sastry C S P, Thirupathi Rao T, Sailaja A and Venkateshwara Rao J, Indian Drugs, 1991, 28, 489.

25. EL-Ashry S M and Irbahim F A, Anal. Lett, 1992, 25, 1657.

26. Mahadik K R, Rudraawas D G, More H N and Kadam S S, Indian Drugs, 1991,28, 530.

27. Sanghavi N M, Samarth M M and Warrier J, Indian Drugs, 1991, 28, 567.

28. Jovanovic T, and Stankovic B, Korieanac Z, J Pharm Biomed Anal, 1995, 13, 213.

29. Sastry C S P, Srinivas K R and Prasad K M M K, Anal Lett, 1996, 29, 1329.

30. Sastry C S P, Rao S G, Naidu P Y and Srinivas K R, Anal Lett, 1998, 31,263.

31. Emara K M, Mohamad A M I, Askal H F and Darwish I A, Anal Lett, 1993, 26,2385.

32. Vogel A I, Text Book of Quantitative inorganic analysis, (eds.). 3, (ELBS, Longman, London) 1978, 349.

33. Kratochril B and White M C, Anal Chim Acta, 1964, 31528.

34. Mohr F, Ann., 1958,105 60; cf Muller E and Diefenthaler O Z, Anorg Chem, 1910, 67, 418; Kohn M, Anal Acta, 1954, 10, 405.

35. Muralikrishna U, Shiva Ramakrishna A and Santhishree T A S S, Boce Indian Council of Chemists, 1997, 16 ${ }^{\text {th }}$ Conference, AO-17 P, 159. 


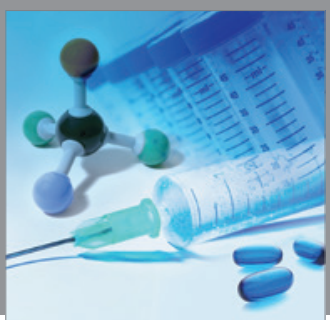

International Journal of

Medicinal Chemistry

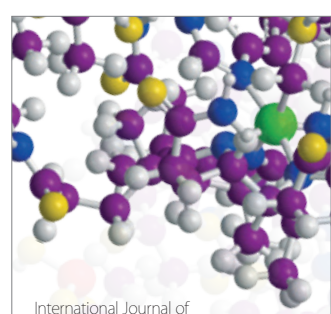

Carbohydrate Chemistry

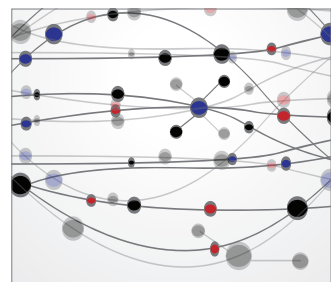

The Scientific World Journal
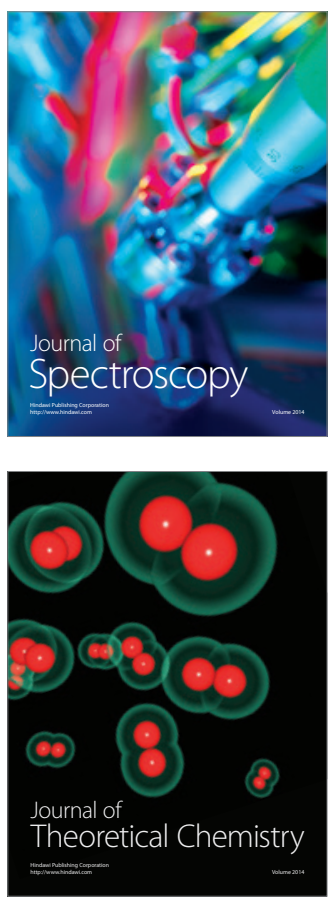
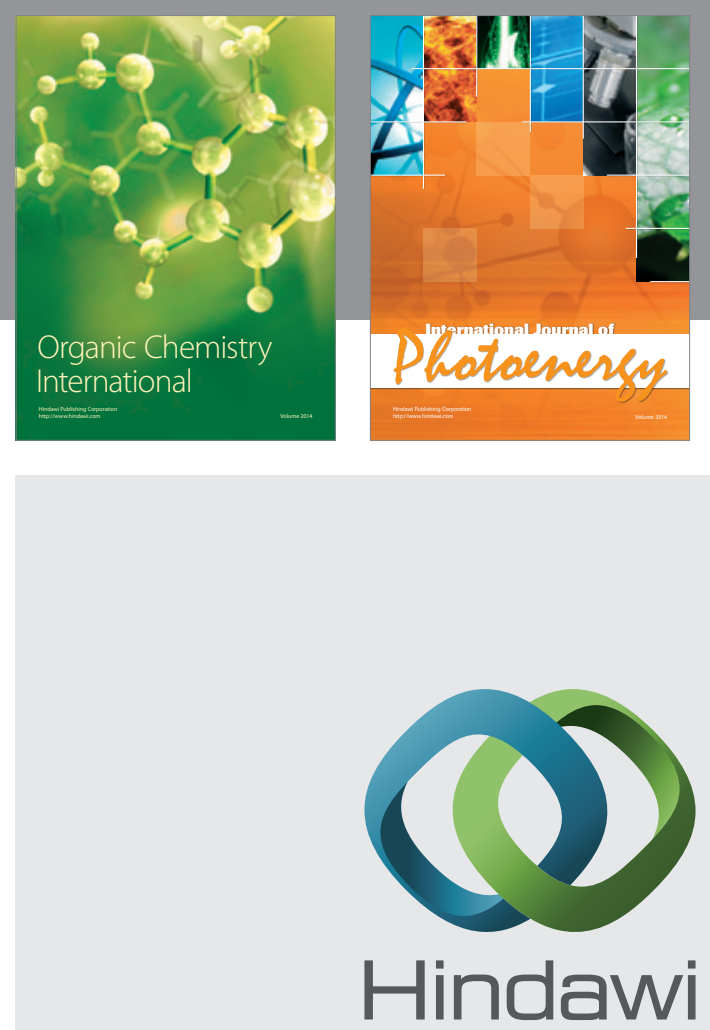

Submit your manuscripts at

http://www.hindawi.com
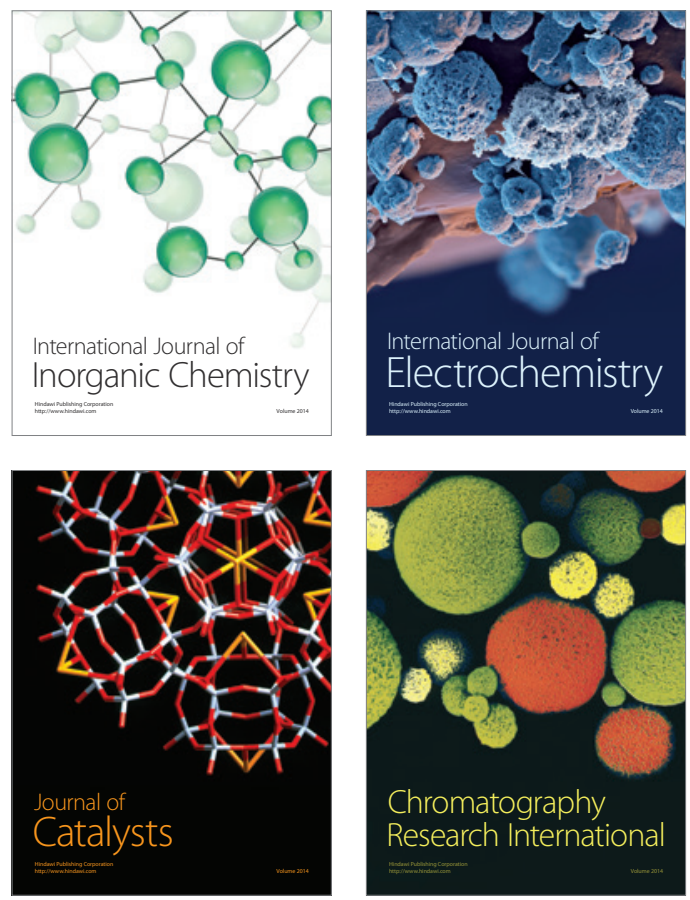
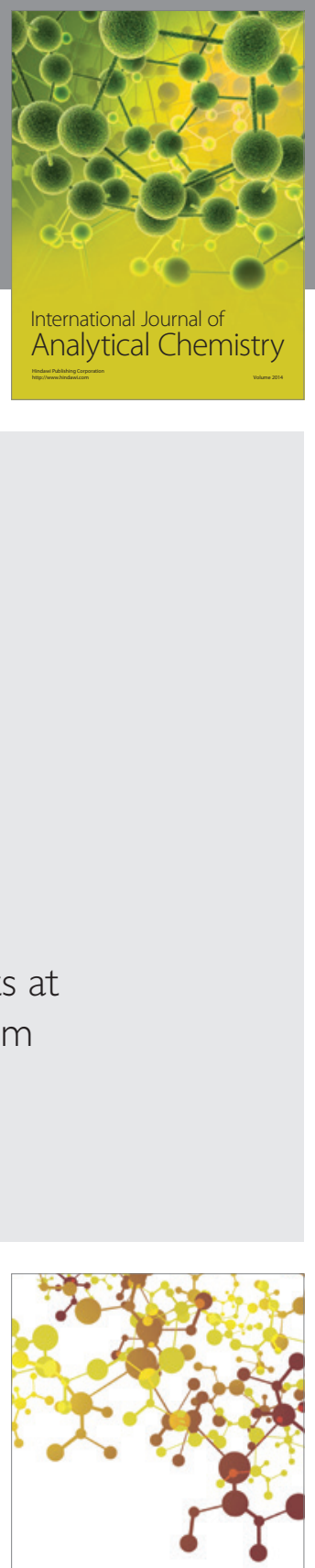

Journal of

Applied Chemistry
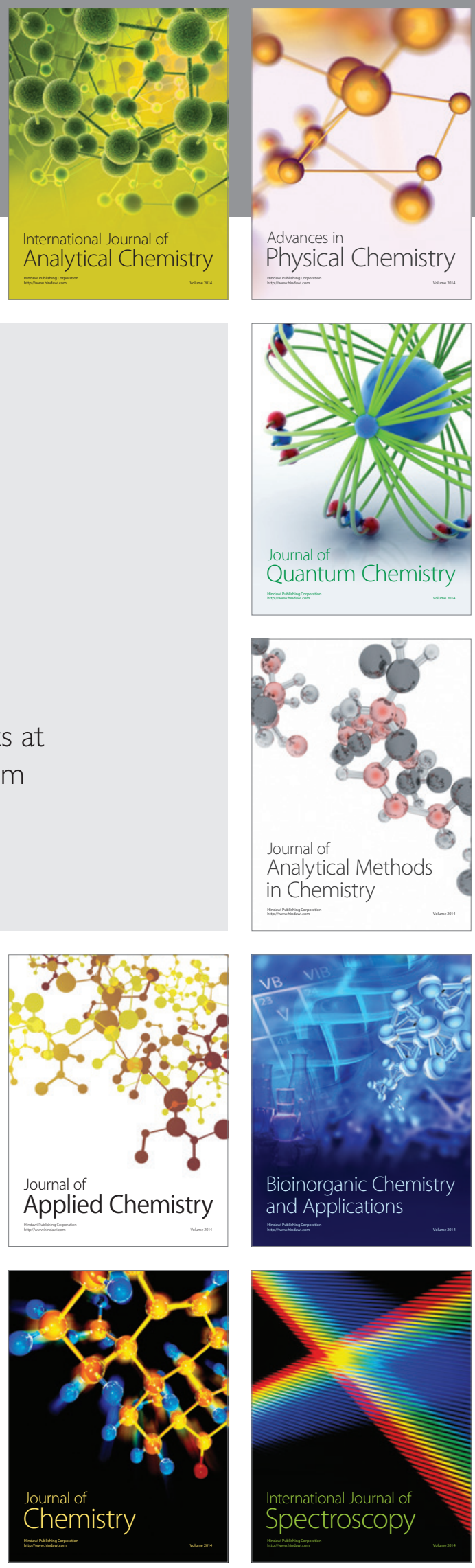